\title{
Experimental and Theoretical Investigation of 3D-Metal Complexes Derived from $\mathrm{N}-(\mathrm{H} H$ - Benzimidazol-2-yl)-2-mercaptoacetamide Derivative
}

\author{
NEELAMMA.M $^{1 *}$, G.H. ANURADHA ${ }^{2}$, S. SREEKANTH ${ }^{1}$ and B. MANOGNA ${ }^{3}$ \\ ${ }^{1}$ Department of Chemistry, University College of Science, Osmania University, \\ Hyderabad-500004, Telangana, India \\ ${ }^{2}$ Department of Chemistry, Sardarpatel College, Padmarao Nagar, \\ Secunderabad-500025, Telangana, India \\ ${ }^{3}$ Anurag Group of Institutions, Venkatapur, Ghatkesar, Medchal (Dist), Hyderabad- 500088, \\ Telangana, India \\ nbudarapu@gmail.com
}

Received 29 November 2018 / Accepted 23 December 2018

\begin{abstract}
New trinuclear metal complexes of $\mathrm{Co}(\mathrm{II}), \mathrm{Ni}(\mathrm{II}), \mathrm{Cu}(\mathrm{II})$ and $\mathrm{Zn}(\mathrm{II})$ with $N$-(1Hbenzimidazol-2-yl)-2-mercaptoacetamide (BMA) were synthesized from chloride salts of relative metals in butanol medium. Synthesized metal complexes were characterized by elemental analysis, conductance measurements, IR, UV-Vis, ESR, TGA \& DTA and magnetic susceptibility measurements. IR spectral data suggest that the ligand behaves as monobasic tridentate (NOS) with donor sites of azomethine nitrogen (ring), oxygen atom of carbonyl group and thio group. Physicochemical data suggest tetrahedral geometry for $\mathrm{Co}(\mathrm{II})$, Ni(II) and $\mathrm{Zn}$ (II) complexes. Square planar intended for $\mathrm{Cu}$ (II) complex and all these complexes exhibits non-elecrolytic nature. The complexes were evaluated for their antimicrobial activity by in-vitro antimicrobial screening against bacteria Staphylococcus aureus, Bacillus subtilis, Escherichia coli and Klebsiella Pneumonia. The results indicate that antimicrobial activity increased during metallation. A detailed analysis is done theoretically using DFT method with B3LYP/6-311G/LanL2DZ functional for ligand and complexes. Docking studies of ligand and metal complexes carried out using OPLS 2005 force field in Schrodinger suite.
\end{abstract}

Keywords: Metal complexes, DFT method, antibacterial, docking studies.

\section{Introduction}

Benzimidazole moiety is a residue which leads most important role in building a variety of biologically active molecules such as vitamin $\mathrm{B}_{12}$, support their potential use as therapeutics. 
This nucleus is very important pharmacophore in medicinal chemistry as well as in modern drug discovery. Benzimidazole is well known with its widespread applications as drugs, dyes, polymers and enzyme ${ }^{1-3}$. Derivatives of benzimidazole exhibits additional applications in some areas as organic luminophores, fluorescent tags for detection of biological important molecules, as DNA, RNA or proteins and enzymes ${ }^{4,5}$, as optical laser and polymer dyes in optoelectronics ${ }^{6,7}$ etc. 2 -Substituted benzimidazole derivatives show anti-hypertensive activities ${ }^{8}$ and anti-influenza ${ }^{9}$. Amino benzimidazole derivatives are remarkable and are found in drugs as well as natural products ${ }^{10}$. Chelating ligands containing $\mathrm{N}, \mathrm{N}, \mathrm{O}$ and $\mathrm{S}$ donor atoms show broad biological activity and are of special interest because of the ways in which they are bonded to the metal ions ${ }^{11}$. It is known that existence of metal ions bonded to biologically active compounds may enhance their activities $^{12-14}$. In view of importance of above, these two scaffolds are selected in the preparation of ligand using butanol medium.

\section{Experimental}

Metal salts and solvents used were E-Merck products. All other chemicals used were of AR grade. Elemental analysis was carried out using micro analytical techniques on Heraeus CHN rapid analytical, metal estimations were done on a Perkin Elmer 2380 atomic absorption spectrometer. Conductivity measurements were carried on Elico digital conductivity meter model No.CM-180. The magnetic susceptibility measurements were done on a factory balance $(\mathrm{CAHN}-7600)$ using $\mathrm{Hg}\left[\mathrm{Co}(\mathrm{SCN})_{4}\right]$ as calibrate. TGA, DTA data was established by using Leeds and Northrop-USA instrument. Infrared spectra were recorded on a Perkin-Elmer 1600. The electronic spectra were recorded on a Shimadzu UV160 spectrophotometer. Thermal studies were carried out using Shimadzu TGA-50H in the nitrogen atmosphere. Metal salts and solvents are used E-Merck product All other chemicals used were Analar grade.

\section{Synthesis of $\mathrm{N}$-(1H-benzimidazol-2-yl)-2-mercaptoacetamide}

2-Aminobenzimidazole (1.33g, $1.0 \mathrm{~m} . \mathrm{mol})$, thioglycollic acid ester $(1 \mathrm{~mL}, 1.0 \mathrm{~m} . \mathrm{mol})$ were dissolved in n-butanol $(10 \mathrm{~mL})$ and mixture was refluxed $2-3 \mathrm{~h}$, yellow coloured compound separates out on cooling and recrystallized from n-butanol. Yield: $75 \%$, M.P: $215{ }^{\circ} \mathrm{C}$.

The compound is stable to air and moisture. Its purity was checked with TLC using different solvent mixtures. BMA is crystalline and is soluble in common organic solvents like $\mathrm{CH}_{3} \mathrm{OH}, \mathrm{CHCl}_{3}$ and acetone etc. $\mathrm{BMA}\left(\mathrm{C}_{9} \mathrm{H}_{9} \mathrm{~N}_{3} \mathrm{OS}\right.$ ) yellow powder (Figure 1). Melting point: $215^{\circ} \mathrm{C}$; UV $(\mathrm{EtOH}) \lambda_{\max } / \mathrm{nm}=249 \mathrm{~nm}, 293 \mathrm{~nm}$ and $425 \mathrm{~nm}$; IR (diamond): $v / \mathrm{cm}^{-1}=$ 3270, 3109, 1607, 1564, 2672, 691; 1H NMR (DMSO-d6, $300 \mathrm{MHz}$ ): $\delta / \mathrm{ppm}=\delta 2.1(\mathrm{~s}, 2 \mathrm{H}$ ), $\delta 5.8$ (broad s, $\left.1 \mathrm{H}, \mathrm{NH}_{\mathrm{Benz}}\right), \delta 7.2(\mathrm{~m}, 4 \mathrm{H} \mathrm{Ar})$; Anal. Calcd for $\mathrm{C}_{9} \mathrm{H}_{9} \mathrm{~N}_{3} \mathrm{OS}\left(207.25 \mathrm{gmmol}^{-1}\right)$ (\%): C, 52.16; H, 4.34; N, 20.28; S, 15.45; Found: C, 52.11; H, 4.36; N, 20.28; S, 15.40. Mass m/e: 173,160, 133,132,105, 90 (Figure 2).

\section{Synthesis of transition metal complexes}

$\mathrm{N}$-(1H-Benzoimidazol-2-yl)-2-mercaptoacetamide (BMA) (0.21 g, $1 \mathrm{mmol}$ ) was added drop wise to solution of divalent metal chloride $\mathrm{Co}$ (II) (0.238 g), Ni(II) (0.237 g), Cu(II) $(0.172 \mathrm{~g})$ and $\mathrm{Zn}(\mathrm{II})(0.132 \mathrm{~g})(1 \mathrm{~m} . \mathrm{mol})$ in $10 \mathrm{~mL}$ absolute methyl alcohol. The $\mathrm{pH}$ of the mixture was adjusted to 7 using $5 \%$ ammonia- $\mathrm{CH}_{3} \mathrm{OH}$ mixtures and refluxed for $3-4 \mathrm{~h}$ complex which separated was filtered in hot condition, washed with a small portion of cold methanol and diethyl ether and dried in vacuum. The purity of metal complexes was tested by TLC using different solvent mixtures. Yield: 50-60\%. 


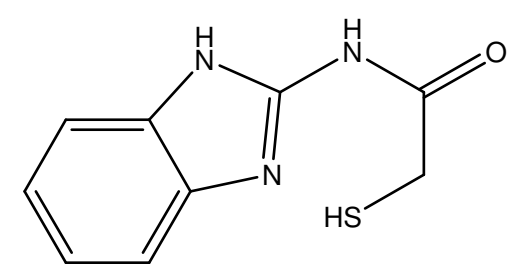

Figure 1. Structure of ligand(BMA)<smiles>O=C(O)NC1Nc2ccccc2N1</smiles>

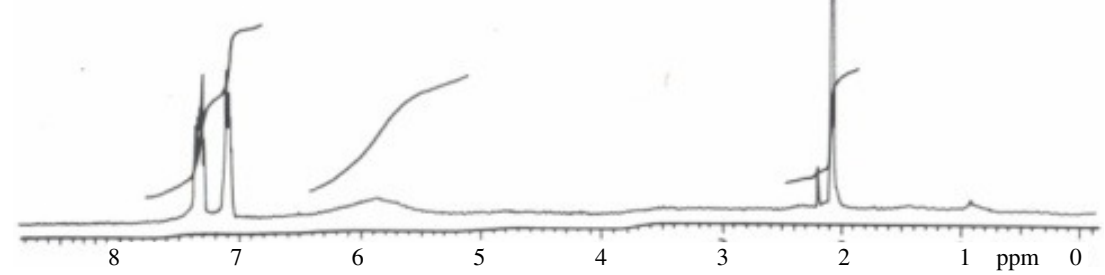

Figure 2. NMR spectra of BMA

All the metal complexes except $\mathrm{Zn}$ (II) are colored and stable to air and moisture. They decompose at high temperatures. They are soluble in DMF and DMSO and insoluble in common organic solvents like methanol, acetone and chloroform.

[CoLCl] $.5 \mathrm{H}_{2} \mathrm{O}$ (1): Black, M.P. $>350{ }^{\circ} \mathrm{C}$, yield 42\%, $\mu_{\text {eff: }}$ 3.58BM. Anal. Calcd for $\mathrm{C}_{9} \mathrm{H}_{18} \mathrm{~N}_{3} \mathrm{O}_{6} \mathrm{SClCo}\left(390.4 \mathrm{~g} . \mathrm{mol}^{-1}\right)(\%): \mathrm{C}, 27.58 ; \mathrm{H} 4.59 ; \mathrm{N}, 10.72 ; \mathrm{S}, 8.17$. Found: C, 27.53; $\mathrm{H}, 4.57 ; \mathrm{N}, 10.67 ; \mathrm{S} 8.13$. IR (selected bands, $\left.\mathrm{cm}^{-1}\right)$ : $v(\mathrm{~N}-\mathrm{H}) 3700-2900 \mathrm{br}, \mathrm{v}(\mathrm{C}=\mathrm{N}), v(\mathrm{C}=\mathrm{O})$ merge 1583, $v(\mathrm{C}=\mathrm{S}) 620$. UV-Vis $\left[\lambda_{\max }, \mathrm{nm}: 1180,818\right.$. Conductance $\left(\mathrm{mho} \mathrm{cm}^{2} \mathrm{~mol}^{-1}\right) 35$.

$[\mathrm{NiLCl}] .2 \mathrm{H}_{2} \mathrm{O}(2)$ : Brown, M.P. $314.0-315.6^{\circ} \mathrm{C}$, yield 39\%, $\mu_{\text {eff: }} 3.92 \mathrm{BM}$. Anal. Calcd for $\mathrm{C}_{9} \mathrm{H}_{12} \mathrm{~N}_{3} \mathrm{O}_{3} \mathrm{SClNi}\left(336.19 \mathrm{~g} \mathrm{~mol}^{-1}\right)(\%)$ : C, 32.02; H, 3.55; N, 12.45; S, 9.48\%. Found: C,31.98; H, 3.53; N, 12.41; S, 9.47. IR (selected bands, $\left.\mathrm{cm}-{ }^{-1} 1\right): v(\mathrm{~N}-\mathrm{H}) 3726-2792 \mathrm{br}$, $v(\mathrm{C}=\mathrm{N}), v(\mathrm{C}=\mathrm{O})$ merge $1584 v(\mathrm{C}=\mathrm{S}) 630$. UV-Vis $\left[\lambda_{\max }, \mathrm{nm}: 1126,600\right.$. Conductance (mho $\left.\mathrm{cm}^{2} \mathrm{~mol}^{-1}\right) 28$.

[CuLCl] (3): Dark green, M.P. $>350{ }^{\circ} \mathrm{C}$, yield 73\%, $\mu_{\text {eff }}: 1.98$ BM. Anal. Calcd for $\mathrm{C}_{9} \mathrm{H}_{8} \mathrm{~N}_{3} \mathrm{O}_{3} \mathrm{SClCu}\left(337.0 \mathrm{~g} \mathrm{~mol}^{-1}\right)(\%): \mathrm{C}, 36.28 ; \mathrm{H}, 2.61 ; \mathrm{N}, 13.72 ; \mathrm{S}, 10.45 \%$. Found: $\mathrm{C}$, 35.22; H, 2.58; N, 13.69; S, 10.42. IR (selected bands, $\left.\mathrm{cm}^{-1}\right): v(\mathrm{~N}-\mathrm{H}) 3600-2700 \mathrm{br}, v(\mathrm{C}=\mathrm{N})$ $1601, v(\mathrm{C}=\mathrm{O}) 1672 v(\mathrm{C}=\mathrm{S})$ 617. UV-Vis $\left[\lambda_{\max }(\log \varepsilon), \mathrm{nm}:\right.$ 640, 520.Conductance (mho $\left.\mathrm{cm}^{2} \mathrm{~mol}^{-1}\right) 40$.

[ZnLCl] (4): Pale yellow, M.P. $>350{ }^{\circ} \mathrm{C}$, yield 70\%, $\mu_{\text {eff }}$ : Dia mag. Anal. Calcd for $\mathrm{Zn}\left(\mathrm{C}_{9} \mathrm{H}_{8} \mathrm{~N}_{3} \mathrm{O}_{3} \mathrm{SCl}\left(338.8 \mathrm{~g} \mathrm{~mol}^{-1}\right)(\%): \mathrm{C}, 35.12 ; \mathrm{H}, 2.60 ; \mathrm{N}, 13.65 ; \mathrm{S}, 10.40 \%\right.$. Found: $\mathrm{C}$, 35.08; H, 2.57; N, 13.62; S, 10.50. IR (selected bands, $\left.\mathrm{cm}^{-1}\right): \quad v(\mathrm{~N}-\mathrm{H}) 3700-2800$ br, $v(\mathrm{C}=\mathrm{N}) 1572, v(\mathrm{C}=\mathrm{O}) 1630 v(\mathrm{C}=\mathrm{S}) 619$. UV-Vis $\left[\lambda_{\max }, \mathrm{nm}: 640,520\right.$. Conductance (mho $\left.\mathrm{cm}^{2} \mathrm{~mol}^{-1}\right) 12$. 


\section{Biological activity}

Biological activity of complexes 1-4 was tested against gram positive bacteria, (Staphylococcus aureus and Bacillus subtilis) and gram negative bacteria (Escherichia coli, and Klebsiella Pneumonia) using Muller Hinton nutrient agar media by the well diffusion technique ${ }^{15}$. The results were recorded as zones of inhibition in $\mathrm{mm}$ and compared with the standard drug streptomycin for antibacterial activity.

\section{Computational methods}

Nowadays, computational methods based on density functional theory (DFT) have been widely used. The studies indicate that density-functional theory (DFT) is a powerful tool for predicting geometry and stability of the molecules ${ }^{16-19}$. A visual representation of the molecular geometry is obtained with the aid of the animation option of Gauss View 5.0 graphical interface ${ }^{20}$. In order to understand the vibrational properties, structural characteristics of the ligand BMA and of complexes the density functional theory (DFT) method with B3LYP/6-311G the basis set while the metal atoms were optimized using LANL2DZ functional. To show the existence of intramolecular charge transfer (ICT) within molecular system energies of the highest occupied molecular orbital (HOMO), lowest unoccupied molecular orbital (LUMO) levels and the molecular electrostatic potential (MEP) energy surface are studied.

\section{Docking studies: Methodology}

Ligand and metal complexes were constructed in ChemDraw and minimized using MM2 protocol. Crystal structure of DNA was downloaded from protein data bank (www.rcsb.org) pdb id: $1 \mathrm{~N} 37^{21}$, it was prepared by protein preparation wizard applying OPLS 2005 force field in Schrodinger suite 2010. The prepared DNA was imported into AutoDockTool ${ }^{22}$, binding site was defined around the bound crystal ligand and a grid was prepared using Autogrid4. The ligand and metal complexes were docked into the DNA major groove.

\section{Results and Discussion}

\section{Characterization of the ligand (BMA)}

The IR spectrum (Figure 3a) of BMA shows a peak at $3270 \mathrm{~cm}^{-1}$ assigned to stretching vibration of free $v \mathrm{NH}$. A band due to ring $v \mathrm{NH}$ vibration is observed at $3109 \mathrm{~cm}^{-1}$. A band at 1607 and $1564 \mathrm{~cm}^{-1}$ are ascribed to $\mathrm{vC}=\mathrm{O}$ and ring $\mathrm{vC}=\mathrm{N}$ respectively. A band at $2672 \mathrm{~cm}^{-1}$ is assigned to $v \mathrm{SH}$ and $691 \mathrm{~cm}^{-1}$ is assigned to $v \mathrm{C}-\mathrm{S}$. The electronic spectrum (Figure b) of BMA shows absorptions at $249 \mathrm{~nm}, 293 \mathrm{~nm}$ and $425 \mathrm{~nm}$. The high energy band at $249 \mathrm{~nm}$ is attributed to $\pi \rightarrow \pi^{*}$ transitions of benzimidazole. The band at $293 \mathrm{~nm}$ is due to benzene moiety. The other band at $425 \mathrm{~nm}$ is assigned due to azomethine group.

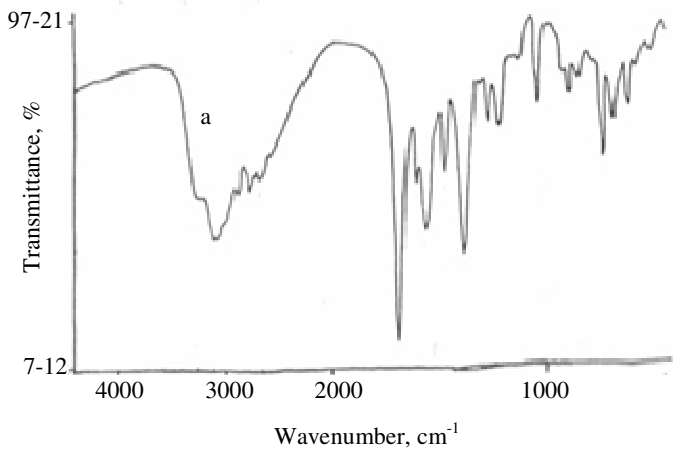



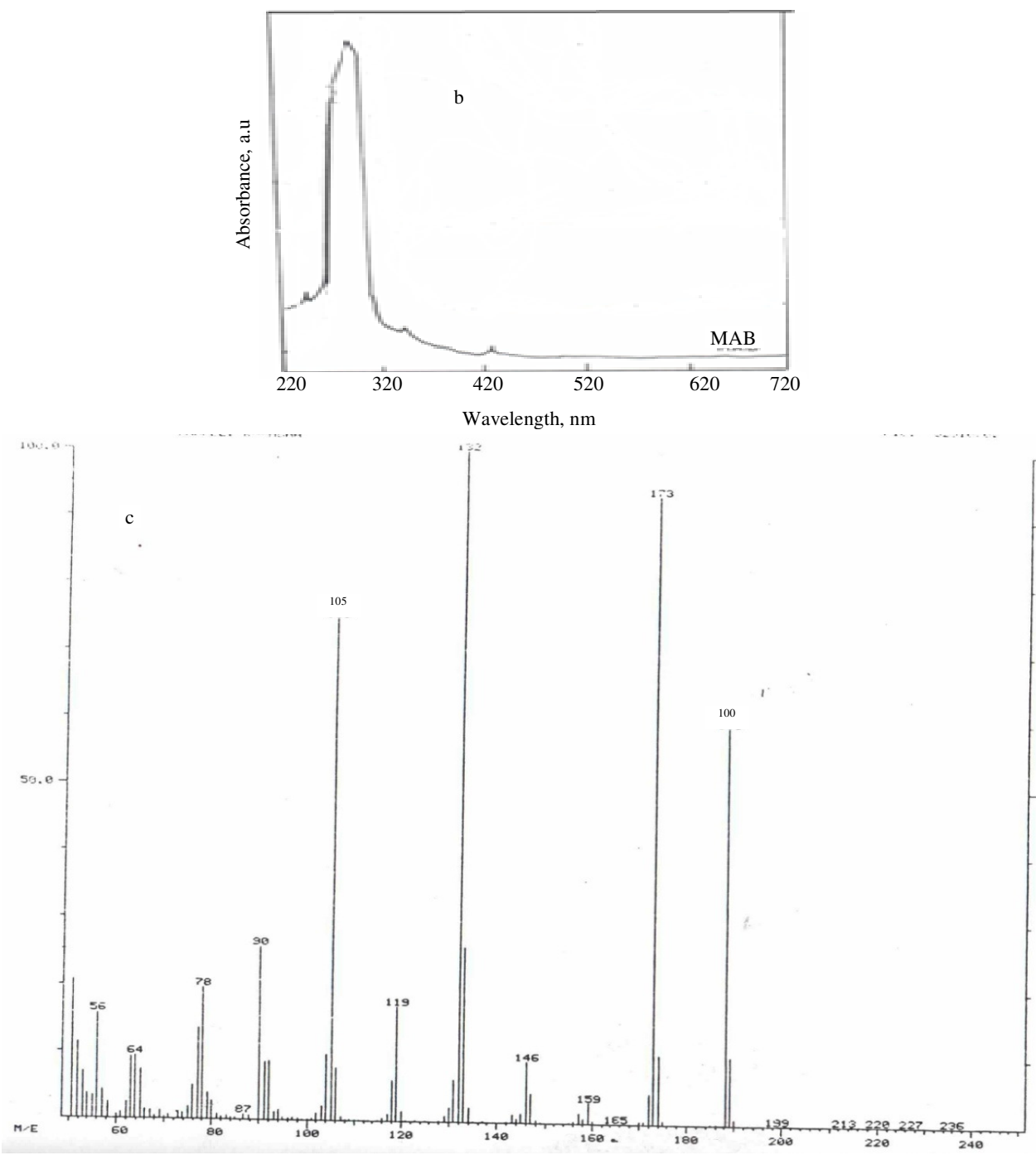

Figure 3. Spectra of BMA (a) IR (b) Electronic and (c) Mass spectra

\section{Characterization of the complexes}

Elemental analysis shows that the metal to ligand ratio is 1:1 in all the complexes. The data suggests the presence of one chloride per divalent metal ions. The low molar conductance values of all the complexes in the range $21-40 \mathrm{mhocm}^{2} \mathrm{~mol}^{-1}$ at room temperature indicate non electrolytic nature of the metal complexes. Analytical and conductance data indicate that the ligand is behaving as a monobasic one.

\section{Thermal analysis of BMA metal complexes}

The data of $\mathrm{Co}(\mathrm{II})$ and $\mathrm{Ni}(\mathrm{II})$ complexes show endotherms relatively at lower temperature in the range of $90^{\circ} \mathrm{C}$ to $115^{\circ} \mathrm{C}$ which can be attributed to crystal water. The endotherm is succeeded by an intense and broad exotherm in the range of $190{ }^{\circ} \mathrm{C}$ to $510{ }^{\circ} \mathrm{C}$ which may represent the completion of the decomposition. 


\section{IR spectra of BMA metal complexes}

In all the complexes there is downward shift in $v \mathrm{C}=\mathrm{N}$ and $v \mathrm{C}=\mathrm{O}$. In $\mathrm{Co}$ (II) and $\mathrm{Ni}$ (II) complexes the strong intense broad band observed at $1560 \mathrm{~cm}^{-1}$ is assumed to arise due to merger of $v \mathrm{C}=\mathrm{O}, v \mathrm{C}=\mathrm{N}$. The IR spectra of the complexes provide evidence in support of the involvement of SH group in coordination. This indicated by the downward shift of $v \mathrm{C}-\mathrm{S}$. The $v C$-S band observed at $691 \mathrm{~cm}^{-1}$ in free ligand shows negative shift in complexes up to $617 \mathrm{~cm}^{-1}$ as shown in Table 1 . Disapperance of $v \mathrm{~S}-\mathrm{H}$ in complexes is evidence that ' $\mathrm{S}$ ' coordinated with metal with dissociation of '-SH' proton. The spectra do not provide any confirmatory evidence regarding deprotonation of SH. IR spectra of the complexes are given in Figure 4 and data in Table 1. In $\mathrm{Co}$ (II) and Ni(II) complexes also the broad band located in the range of 3700 to $2700 \mathrm{~cm}^{-1}$ is attributed to $\mathrm{OH}\left(\mathrm{H}_{2} \mathrm{O}\right)$ and $\mathrm{NH}$. The non-ligand bands in the range of $655-460 \mathrm{~cm}^{-1}$ are assigned to $\mathrm{M}-\mathrm{O}, \mathrm{M}-\mathrm{S}$ and $\mathrm{M}-\mathrm{N}^{23}$ modes. The $\mathrm{M}-\mathrm{Cl}$ bands are identified at $370-250 \mathrm{~cm}^{-1}$. This is indicating that binding to the metal is through a NOS sequence involving the ring azomethine nitrogen, carbonyl oxygen and deprotonated thiolic group. The presence of chloride in complexes was identified by Volhard's test ${ }^{24}$.

Table 1. IR data of ligand and complexes

\begin{tabular}{ccccccc}
\hline Lig/complexes & $v \mathrm{NH}$ & $v \mathrm{C}=\mathrm{N}$ & $v \mathrm{C}=\mathrm{O}$ & $v \mathrm{C}-\mathrm{S}$ & $v \mathrm{SH}$ & New bonds \\
\hline BMA & $3109-3270$ & 1564 & 1687 & 691 & 2672 & \\
\hline Co(II)complex & $3700-2900$ & 1583 & 620 & & $883,695,560,490$, \\
Ni(II)complex & $3726-2792$ & \multicolumn{2}{c}{1584} & 630 & & $460,370,255$ \\
& \multicolumn{5}{c}{$\leftrightarrow$} \\
Cu(II)complex & $3600-2700$ & 1601 & 1672 & 617 & & $490,702,630,469$, \\
Zn(II)complex & $3700-2800$ & 1572 & 1630 & 619 & & $735,330,270,250$ \\
\hline
\end{tabular}
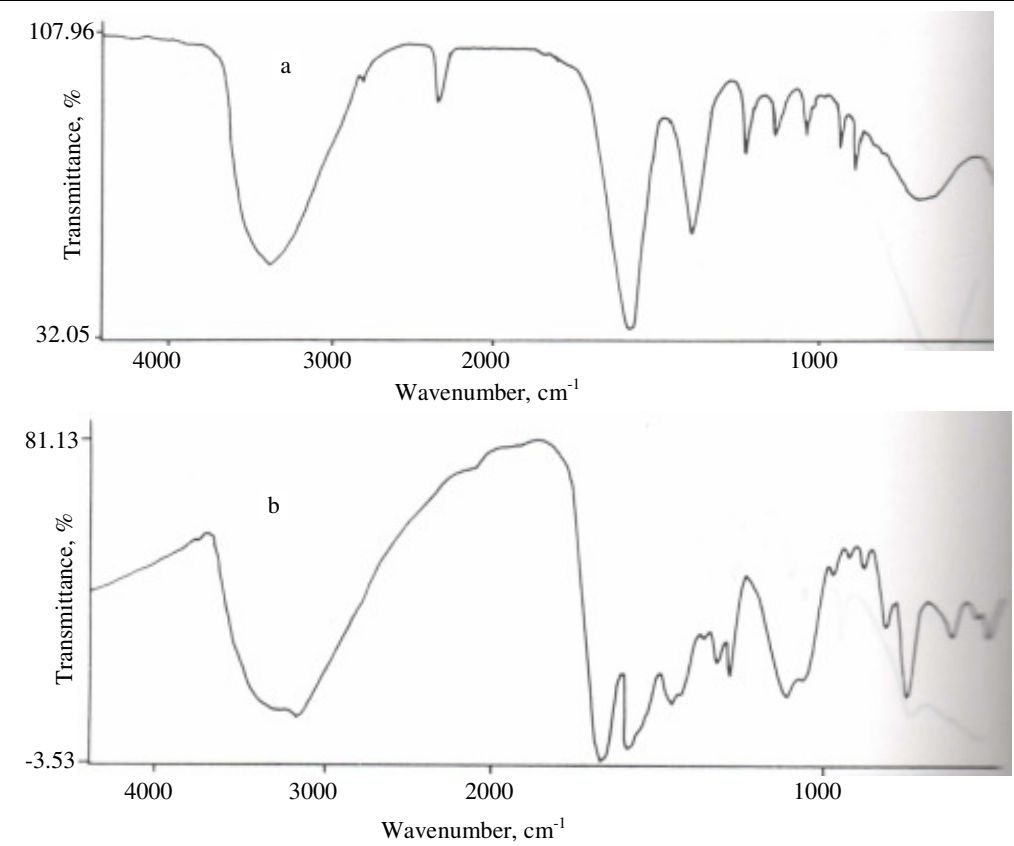

Figure 4. IR spectra of (a) $\mathrm{Ni}$ (II) and (b) $\mathrm{Cu}$ (II)-BMA complexes 


\section{Magnetic data of BMA complexes}

The magnetic moment values of $\mathrm{Co}(\mathrm{II})$ and $\mathrm{Ni}$ (II) complexes are 3.58 and 3.92 B.M. respectively. In $\mathrm{Cu}$ (II) complex the magnetic moment value is 1.98 B.M. which corresponds to one unpaired electron.

\section{Electronic spectra of BMA metal complexes}

The absorption spectrum of $\mathrm{Co}(\mathrm{II})$ complex shows a high intensity band at $1180 \mathrm{~nm}$ and medium intensity band at $818 \mathrm{~nm}$. These bands are assigned to ${ }^{4} \mathrm{~A}_{2} \rightarrow{ }^{4} \mathrm{~T}_{1}(\mathrm{~F})$ and ${ }^{4} \mathrm{~A}_{2} \rightarrow{ }^{4} \mathrm{~T}_{1}(\mathrm{P})$ transitions respectively tetrahedral geometry is proposed.

The absorption spectrum of $\mathrm{Ni}(\mathrm{II})$ complex shows a high intensity band at $1126 \mathrm{~nm}$ and medium intensity band at $600 \mathrm{~nm}$. These bands are assigned to ${ }^{3} \mathrm{~T}_{1} \rightarrow{ }^{3} \mathrm{~A}_{2}$ and ${ }^{3} \mathrm{~T}_{1}(\mathrm{P})$ transitions respectively. Tetrahedral geometry is proposed.

The absorption spectrum of $\mathrm{Cu}(\mathrm{II})$ complex shows a broad multiple band in the range of $640 \mathrm{~nm}$ to $520 \mathrm{~nm}$ which can be assigned to a combination of three transitions from ${ }^{2} \mathrm{~B}_{1}$ ground state to ${ }^{2} \mathrm{~B}_{2},{ }^{2} \mathrm{~A}_{1},{ }^{2} \mathrm{E}$ states. Square planar geometry is proposed.

\section{ESR spectra of $C u(I I)-B M A$ complex}

The ESR spectrum of BMA-Cu(II) complex was recorded at room temperature and shown in the Figure 5. DPPH with a g value of 2.0036 was used as standard. The spectrum apparently consists of a single intense signal. The tendency of the g-tensor exhibiting isotropic behaviour. The $\mathrm{g}$ value evaluated from the spectrum $\left(\mathrm{g}_{\text {iso }} 2.043\right)$ supports this isotropic nature. The reason for getting a single ESR spectrum may be due to the exchange coupling interactions among $\mathrm{Cu}(\mathrm{II})$ ions. However g value (2.043) indicates that the electron in the $\mathrm{Cu}$ (II) ion is largely delocalized. The A value is $130 \mathrm{G}$. Square planar geometry around $\mathrm{Cu}(\mathrm{II})$ is confirmed by other experimental data.

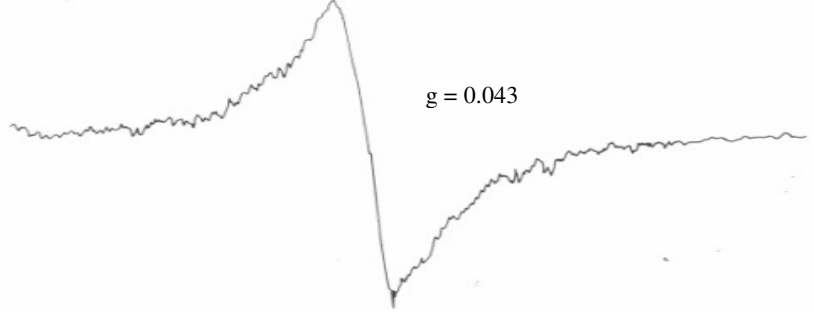

Figure 5. ESR spectra of Cu-BMA complex

\section{Biological activity}

Antimicrobial activity of the ligand L and its complexes 1-4 were tested against four pathogenic bacteria species by the well diffusion method (Table 2). The study indicated that the complexes 1-4 exhibited higher antimicrobial activity than the free ligand L and their activity depended upon the size and charge distribution of metal ions, shape and redox potential of the metal chelates ${ }^{25}$. The complexes $\mathbf{3}$ and $\mathbf{4}$ were more potent than the other ones. The increased inhibition activity of complexes can be explained on the basis of the Overtone's concept and Tweedy's Chelation hypothesis ${ }^{26}$. The observed zones of inhibition for the complexes 1-4 followed the order: control $>\mathbf{3}>\mathbf{4}>\mathbf{1}>\mathbf{2}>\mathrm{L}$ that matched the computational studies. This can be elucidated on the basis of Structure-Activity Relationship $^{27}$ (SAR). Complexes $\mathbf{1}$ and 2 are less active due to the low lipophilicity of $\mathrm{M}(\mathrm{II})$ ion and low penetration of these complexes through the lipid membrane. 
Table 2. Antibacterial activities of the ligand and its complexes 1-4 by the well diffusion method

\begin{tabular}{ccccccccc}
\hline $\begin{array}{c}\text { Organism } \\
\text { Sample }\end{array}$ & $\begin{array}{c}\text { Staphylococcus } \\
\text { aureus }\end{array}$ & \multicolumn{2}{c}{ Bacillus subtilis } & Escherichia coli & $\begin{array}{c}\text { Klebsiella } \\
\text { Pneumonia }\end{array}$ \\
\hline Concentration & $1 \mathrm{mg} / \mathrm{mL}$ & $0.5 \mathrm{mg} / \mathrm{mL}$ & $1 \mathrm{mg} / \mathrm{mL}$ & $0.5 \mathrm{mg} / \mathrm{mL}$ & $1 \mathrm{mg} / \mathrm{mL}$ & $0.5 \mathrm{mg} / \mathrm{mL}$ & $1 \mathrm{mg} / \mathrm{mL}$ & $0.5 \mathrm{mg} / \mathrm{mL}$ \\
\hline $\begin{array}{c}\text { BMA (L) } \\
\text { 1. Co(II) }\end{array}$ & 18 & 11 & 16 & 11 & 18 & 12 & $\mathrm{NA}$ & $\mathrm{NA}$ \\
$\begin{array}{c}\text { complex } \\
\mathbf{2} \text {.Ni(II) }\end{array}$ & 29 & 19 & 26 & 19 & 24 & 16 & 19 & 17 \\
$\begin{array}{c}\text { complex } \\
\text { 3.Cu(II) }\end{array}$ & 24 & 14 & 19 & 15 & 21 & 15 & 16 & 13 \\
$\begin{array}{c}\text { complex } \\
\mathbf{4} \text {.Zn(II) }\end{array}$ & 43 & 28 & 39 & 29 & 39 & 26 & 28 & 21 \\
$\begin{array}{c}\text { complex } \\
\text { streptomycin }\end{array}$ & 49 & 23 & 32 & 21 & 36 & 22 & 21 & 18 \\
\hline
\end{tabular}

\section{Computational Studies}

\section{Frontier molecular orbital analysis}

The HOMO and LUMO frontier orbital, determine the way the molecule interacts with other species. The HOMO is the orbital that primarily acts as an electron donor and LUMO is the orbital that largely acts as electron acceptor and the gap between HOMO and LUMO characterizes the stability and light on chemical reactivity of the molecule ${ }^{28}$. The computed energy gap $(\Delta \mathrm{E})$ for the ligand BMA as well as the complexes given in Table 3 (Figure 6). The frontier orbital energy gaps of 1.6915-2.6468 eV in the complexes indicate d-d transitions and are in accordance with the eminent broad shoulder found from the electronic spectra.

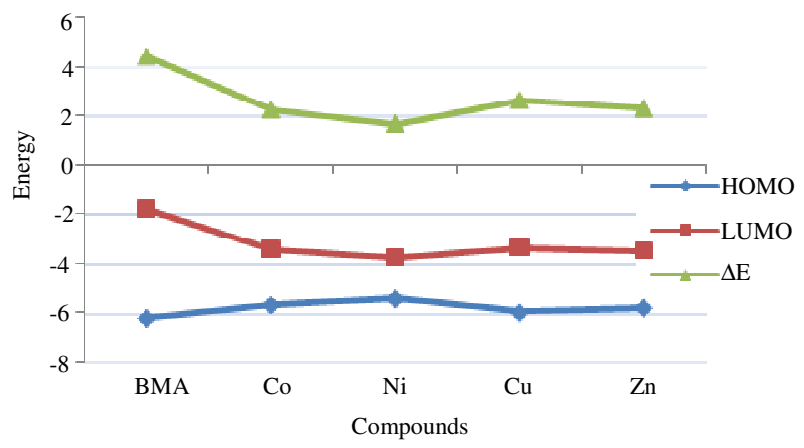

Figure 6. HOMO, LUMO and $\triangle \mathrm{E}$ of ligand and metal complexes

\section{Molecular electrostatic potential (MEP) of ligand and its complexes}

To predict reactive sites for electrophilic and nucleophilic attack for the title molecule, MEP maps were generated from the molecular orbital energies obtained from DFT calculations. The molecular electrostatic potential surface displays molecular shape, size and electrostatic potential values of (BMA) and its complex. The molecular electrostatic potential (MEP) surface diagram is related to the electronic density and is a very useful descriptor in understanding sites for electrophilic attack and nucleophilic reactions as well as hydrogenbonding interactions ${ }^{29-31}$. The negative regions can be regarded as nucleophilic centers, and 
the positive regions as potential electrophilic sites in the electrostatic potential map (Figure 7). The hydrogen atoms in ligand BMA and in case of the complex bear the maximum positive charge. The predominance of green region in the MEP surface corresponds to an electron density distribution in between the two extremes red and dark blue color.

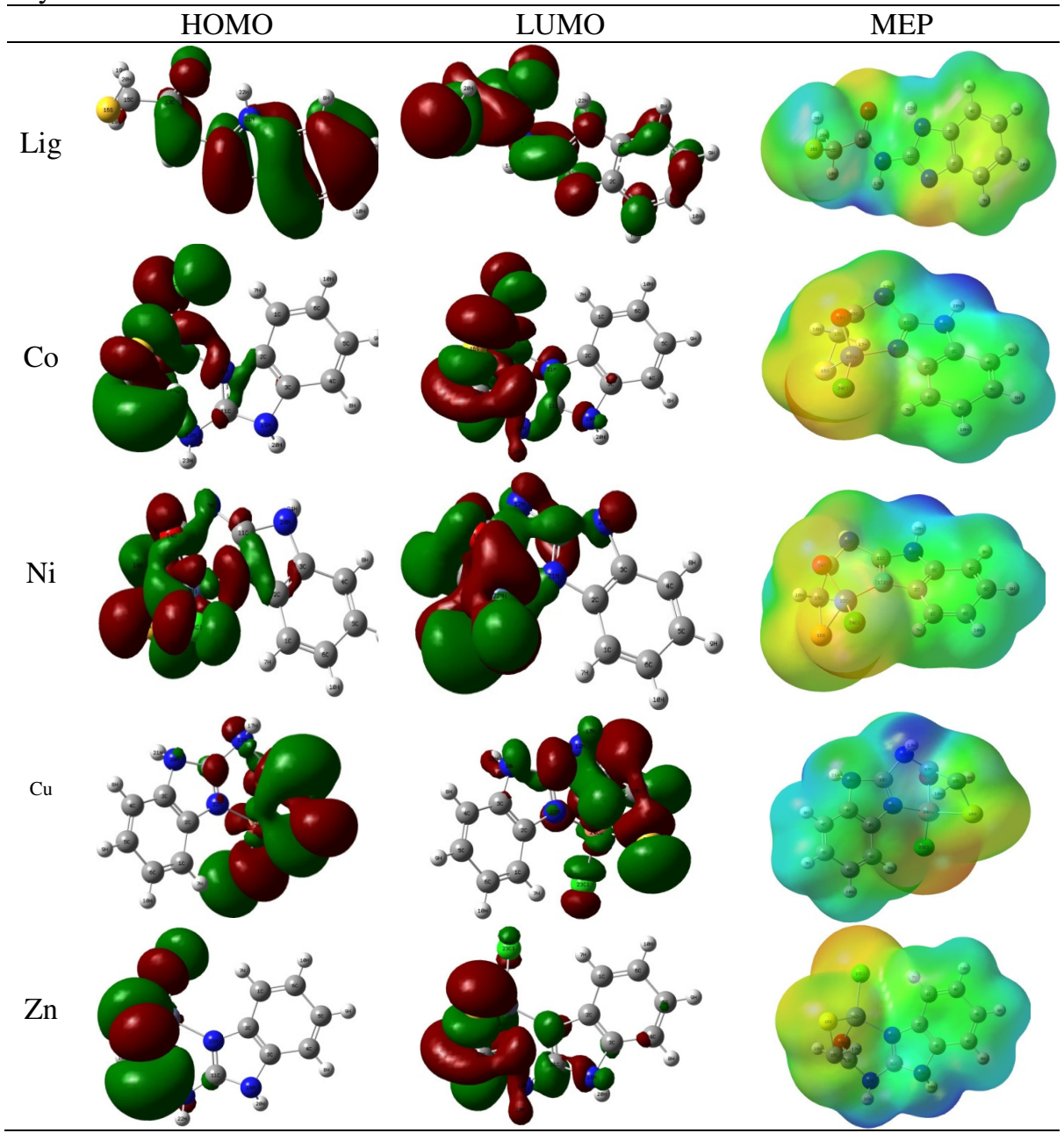

Figure 7. HOMO, LUMO, MEP surface density diagrams of ligand and its complexes.

\section{Reactivity descriptors}

The highest occupied molecular orbital (HOMO) and lowest unoccupied molecular orbital (LUMO) are very important parameters for quantum chemistry. The frontier orbital energy gap helps to distinguish the chemical reactivity and kinetic stability of compounds. Nicomplex is more polarizable due to a small frontier orbital energy gap. This complex is normally associated with a high chemical reactivity termed as soft with low kinetic stability.

The chemical potential $(\mu)$, global hardness $(\eta)$ and electrophilicity (w) are global descriptors which indicate the overall stability of a chemical system. Order of stability is Ligand $>\mathrm{Cu}(\mathrm{II})>\mathrm{Zn}(\mathrm{II})>\mathrm{Co}(\mathrm{II})>\mathrm{Ni}(\mathrm{II})$. Complexes are the more reactive than ligand with the 
lower value of chemical hardness. Hence, the ligand exhibit their greatest affinity toward the $\mathrm{Ni}(\mathrm{II})$ ion and the least toward the $\mathrm{Cu}$ (II) ion. The values of some global reactivity descriptors ${ }^{32-34}$ investigated are presented in Table 3.

Table 3. DFT- 6-311G Basis set Calculation Summary for $\Delta \mathrm{E}$, absolute electronegativity $\left(\chi_{\mathrm{abs}}\right)$, absolute hardness $(n)$, electrophilicity index $(\omega)$, global softness $(\mathrm{s})$ of the ligand and its complexes

\begin{tabular}{llllllll}
\hline Lig/com & HOMO & LUMO & $\Delta \mathrm{E}$ & $\chi_{\text {abs }}=-\mathrm{u}$ & \multicolumn{1}{c}{$\eta$} & $\omega=\mathrm{u}^{2} / 2 \mathrm{n}$ & $\mathrm{S}=1 / \eta$ \\
\hline BMA & -6.2061 & -1.7778 & 4.4283 & -3.9919 & 2.2141 & 3.5985 & 0.4516 \\
$\mathrm{Co}(\mathrm{II})$ & -5.6733 & -3.4077 & 2.2656 & -4.5405 & 1.1328 & 9.0995 & 0.8827 \\
$\mathrm{Ni}(\mathrm{II})$ & -5.4273 & -3.7358 & 1.6915 & -4.5815 & 0.8457 & 12.4094 & 1.1823 \\
$\mathrm{Cu}(\mathrm{II})$ & -5.9786 & -3.3318 & 2.6468 & -4.6552 & 1.3234 & 8.1873 & 0.7556 \\
$\mathrm{Zn}(\mathrm{II})$ & -5.7881 & -3.4752 & 2.3129 & -4.6316 & 1.1564 & 9.2747 & 0.8646 \\
\hline
\end{tabular}

\section{Docking studies}

Methodology

Ligand and metal complexes were constructed in ChemDraw and minimized using MM2 protocol. Crystal structure of DNA was downloaded from protein data bank (www.rcsb.org) pdb id: $1 \mathrm{~N} 37^{35}$, it was prepared by protein preparation wizard applying OPLS 2005 force field in Schrodinger suite 2010. The prepared DNA was imported into Auto Dock Tool ${ }^{36}$, binding site was defined around the bound crystal ligand and a grid was prepared using Autogrid4. The ligand and metal complexes were docked into the DNA major groove. Based on the present studies it may be concluded that the ligand exhibit promising antibacterial activity and activities can be subjected to change through metallation. The dock score and inhibition constant values (Table 4) which are the parameters to determine binding affinity conclude that metal complexes have better binding affinity than free ligand BMA

Table 4. Dock score and inhibition constant of ligand and complexes

\begin{tabular}{ccc}
\hline Complex & $\begin{array}{c}\text { Dock score } \\
(\mathrm{kcal} / \mathrm{mol})\end{array}$ & $\begin{array}{c}\text { Estimated Inhibition } \\
\text { Constant }(\mathrm{Ki} \text { in } \mu \mathrm{M})\end{array}$ \\
\hline BMA & -4.97 & 227.88 \\
Co(II) complex & -5.59 & 79.94 \\
$\mathrm{Ni}(\mathrm{II})$ complex & -5.35 & 119.92 \\
$\mathrm{Cu}$ (II) complex & -5.98 & 41.32 \\
$\mathrm{Zn}$ (II) complex & -5.63 & 75.30 \\
\hline
\end{tabular}
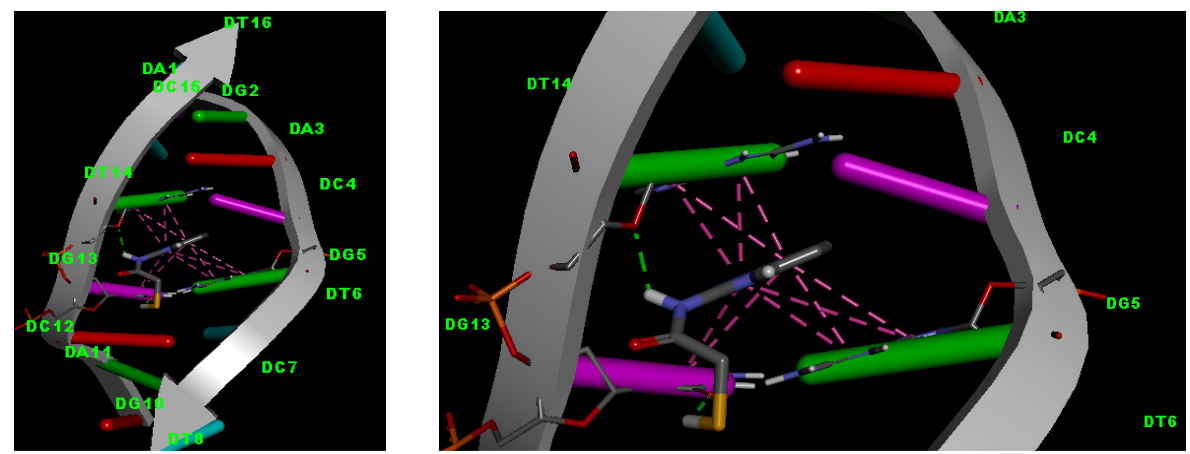

Figure 8. Dock pose of ligand in the major grove of DNA showing hydrogen bond interaction with G13 and $\pi-\pi$ interaction with T14, G13 and G5 
As per docking studies all the metal complexes showed better binding than Ligand, clearly indicating the importance of metal chelation. Copper complex is better in terms of docking studies.
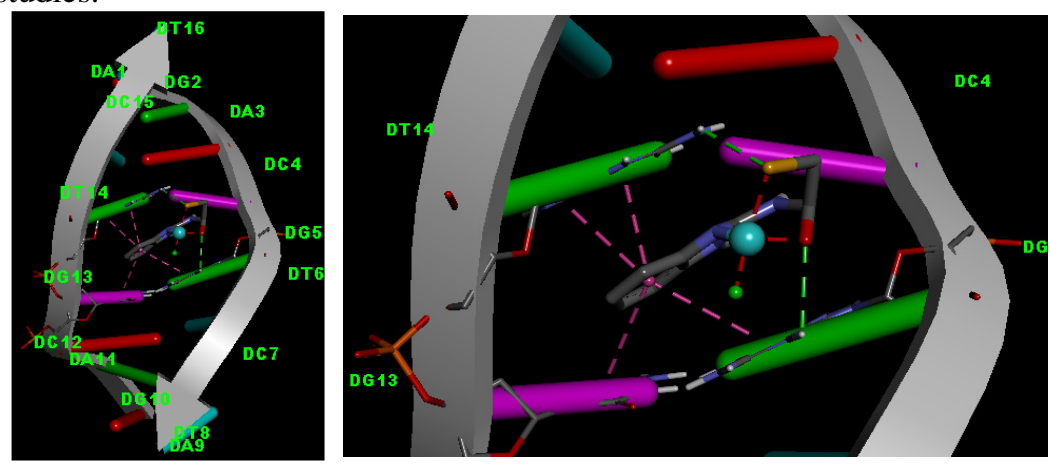

Figure 9. Dock pose of Cu-Complex in the major grove of DNA showing hydrogen bond interaction [green lines] with T14 and G5

The greater binding affinity of complexes is due to the formation of hydrogen bond with G13 (Figures 8-11) and $\pi-\pi$ interaction with [pink lines] with T14 and G5. $\mathrm{Cu}$ (II) complex showed more negative dock score of followed by $\mathrm{Zn}(\mathrm{II}), \mathrm{Co}(\mathrm{II})$ and $\mathrm{Ni}(\mathrm{II})$ complexes. The higher binding affinity of $\mathrm{Cu}-\mathrm{Complex}$ is due to the increase in hydrogen bond interaction than the ligand.
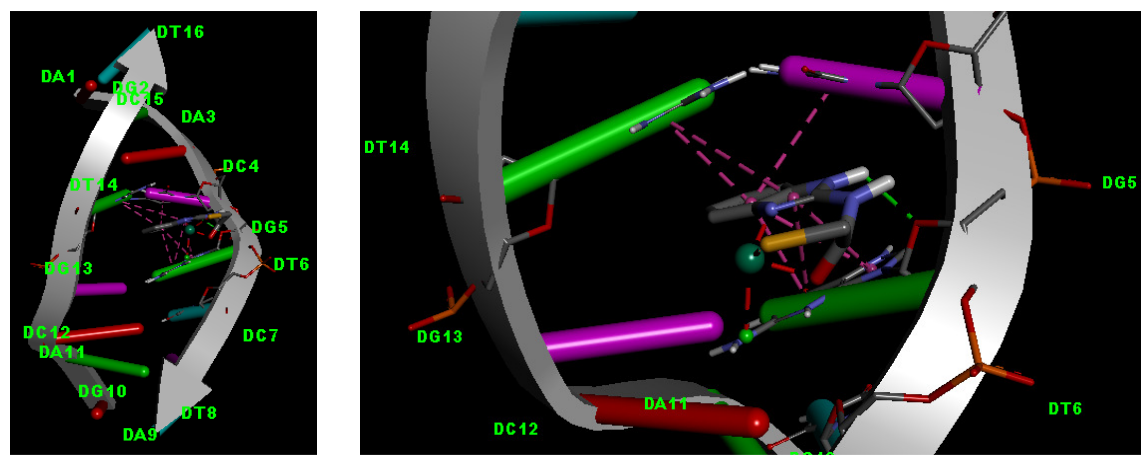

Figure 10. Dock pose of Ni-Complex in the major grove of DNA showing hydrogen bond interaction with G5. Complex also has $\pi-\pi$ interaction with T14, C4 and G5
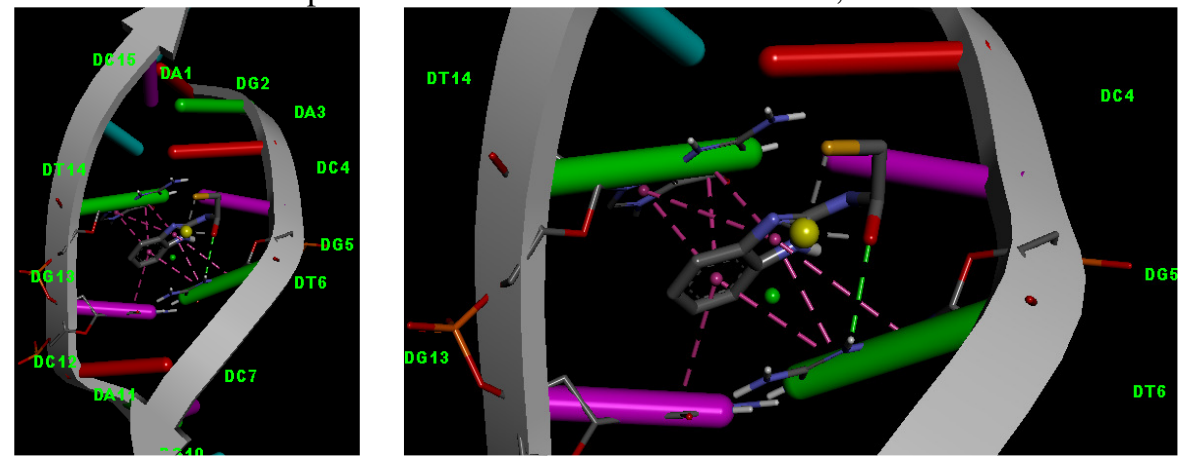

Figure 11. Dock pose of Zn-Complex in the major grove of DNA showing hydrogen bond interaction with G5. Complex also has $\pi-\pi$ interaction with T14, G13 and G5 


\section{Conclusion}

BMA is behaving as a monobasic tridentate system employing the ring azomethine nitrogen carbonyl oxygen, and deprotonated thiolic group thus providing an NOS sequence. All the complexes are homonuclear and are forming 1:1complexes. Based on analytical, thermal, conductivity, magnetic and spectral data tetrahedral geometry have been proposed to Co(II), $\mathrm{Ni}(\mathrm{II})$ and $\mathrm{Zn}(\mathrm{II})$ complexes. Square planar for $\mathrm{Cu}(\mathrm{II})$ complex. Theoretical data reveal that there is a concord with microbial activity of complexes. On coordination of metal complexes enhances the activity than the ligand. The proposed structures are given in the Figure 12.

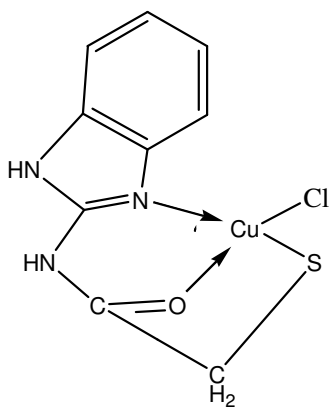

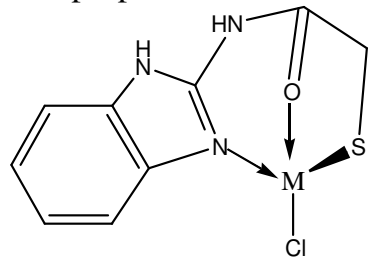

$\mathrm{M}=\mathrm{Zn}(\mathrm{II}) ; \mathrm{X}=0$

$\mathrm{M}=\mathrm{Co}(\mathrm{II}), \mathrm{X}=5$

$\mathrm{M}=\mathrm{Ni}(\mathrm{II}), \mathrm{X}=2$

.X H2O

Figure 12. Tentative structures of Metal complexes

\section{References}

1. Yadav G and Ganguly S, Eur J Med Chem., 2015, 97, 419-443;

DOI:10.1016/j.ejmech.2014.11.053

2. Bansal Y and Silakari O, Bioorg Med Chem., 2012, 20(21), 6208-6236;

DOI:10.1016/j.bmc.2012.09.013

3. Wang T, Zhao Z, Wei B, Zhang L and Ji L, J Mol Struct., 2010, 970, 128-133. DOI:10.1016/j.molstruc.2010.02.061

4. Hranjec M, Pavlovic G, Marjanovic M, Kralj M and Karminski-Zamola G, Eur J Med Chem., 2010, 45, 2405-2417; DOI:10.1016/j.ejmech.2010.02.022

5. Jäger A, Stefani V, Guterres S S and Pohlmann A R, Int J Pharm., 2007, 338, 297305; DOI:10.1016/j.ijpharm.2007.01.051

6. Batista M F R, Susana P G, Costa M, Belsley M and Raposo M M, Tetrahedron, 2007, 63, 9842-9849; DOI:10.1016/j.tet.2007.06.098

7. Nurulla I, Tanimoto A, Shiraishi K, Sasaki S and Yamamoto T, Polymer, 2002, 43, 1287-1293; DOI:10.1016/S0032-3861(01)00681-4

8. Kamal Shah, Sumit Chhabra, Sushant K Shrivastava and Pradeep Mishra, Med Chem Res., 2013, 22(11), 5077-5104; DOI:10.1007/s00044-013-0476-9

9. Wei-Ling Chang, Chin-Shiang Chang, Po-Cheng Chiang, Yunn-Fang Ho, Ju-Fang Liu,Kai-Wei Chang and Jih-Hwa Guh, British J Pharmacol., 2010, 160(7), 16771689; DOI:10.1111/j.1476-5381.2010.00832.x

10. Beaulieu C, Wang Z, Denis D, Greig G, Lamontagne S and Wang J, Bioorg Med Chem Lett., 2004, 14(12), 3195-3199; DOI:10.1016/j.bmcl.2004.04.005

11. (a) Thankamony $M$ and Mohanan K, Indian J Chem A, 2007, 46(2), 247-251; (b) Patra A, Sarkar S, Drew M G B, Zangrando E and Chattopadhyay P, Polyhedron, 2009, 28(7), 1261-1264; DOI:10.1016/j.poly.2009.02.039

12. Raman N, Raja J D and Sakthivel A, J Chem Sci., 2007, 119(4), 303-310; DOI:10.1007/s12039-007-0041-5 
13. Arion V B, Reisner E, Fremuth M, Jokupec M A, Keppler B K, Kukushkin V Y and Pombeiro A J L, J Inorg Biochem., 2003, 96(1), 95; DOI:10.1016/S01620134(03)80556-1

14. Shivakumar K and Halli M B, J Coord Chem., 2006, 59(16), 1847-1856. DOI:10.1080/00958970600655548

15. Chandra S and Gupta L K, Spectrochim Acta A, 2004, 60(7), 1563-1571; DOI:10.1016/j.saa.2004.01.015

16. Maurya R C, Malik B A, Mir J M and Vishwakarma P K, J Mol Struct., 2015, 1083, 343-356; DOI:10.1016/j.molstruc.2014.11.032

17. Denis P and Ventura O N, J Mol Struct., 2001, 537(1-3), 173-180; DOI:10.1016/S0166-1280(00)00674-6

18. Abkowicz-Bienko A J, Bienko D C and Latajka Z, J Mol Struct., 2000, 552(1-3), 165-175; DOI:10.1016/S0022-2860(00)00476-2

19. Banclersen K, Langgard M and Sparget-Larsen J, J Mol Struct., 1999, 509(1-3), 153 163; DOI:10.1016/S0022-2860(99)00217-3

20. GaussView 5.0, Gaussian Inc., Garnegie Office, Park. Pittsburgh, PA, USA.

21. Morris G M, Huey R, Lindstrom W, Sanner M F, Belew R K, Goodsell D S and Olson A J, J Computational Chem., 2009, 16, 2785-91; DOI:10.1002/jcc.21256

22. Adebayo A Adeniyi and Peter A Ajibade, Molecules, 2013, 18, 3760-3778; DOI:10.3390/molecules18043760

23. Graham Patrick, An Introduction to Medicinal Chemistry, $5^{\text {th }}$ Edition, Oxford University Press, 2013.

24. Vogal A I, "A Textbook of Quantitative Inorganic Analysis" $33^{\text {rd }}$ Edition, Londman, London, 1968, 264.

25. Abdel-Rahman L H, Abu-Dief A M, Newair E F and Hamdan S K, J Photochem Photobiol B., 2016, 160, 18-31; DOI:10.1016/j.jphotobiol.2016.03.040

26. Anjaneyulu, Y and Prabhakara Rao R, Synth. React Inorg Met-Org Chem., 1986, 16, 257-272; DOI:10.1080/00945718608057530

27. Muniyandi V, Pravin N, Mitu L and Raman N, J Mol Struct., 2015, 1086, 56-63; DOI: 10.1016/j.molstruc.2015.01.011

28. M. Ozcan, I. Dehri, M. Erbil, Appl. Surf. Sci. 2004, 236, 155-164.

29. Scrocco E and Tomasi J, Adv Quant Chem., 1979, 11, 115-193; DOI:10.1016/S00653276(08)60236-1

30. Luque F J, Lopez J M and Orozco M, Theor Chem Acc., 2000, 103(3-4), 343-345; DOI:10.1007/978-3-662-10421-7_56

31. Okulik N and Jubert A H, Internet Electron J Mol Des., 2005, 4, 17-30.

32. Sun Y, Chen X, Sun L, Guo X and Lu W, J Chem Phys Lett., 2003, 381(3-4), 397 403; DOI:10.1016/j.cplett.2003.09.115

33. Christiansen O, Gauss J, Stanton J F, J Chem Phys Lett., 1999, 305, 147; DOI: $10.1063 / 1.479332$

34. Maurya R C, Malik B A, Mir J M, Vishwakarma P K, Rajak D K and Jain N, J Coord Chem., 2015, 68 (16), 2902-2922; DOI:10.1080/00958972.2015.1064526

35. Searle M S, Maynard A J and Williams H E, Org Biomol Chem., 2003, 1(1), 60-66; DOI:10.1039/B208622K

36. Michel F Sanner, J Mol Graphics Mod., 1999, 17(1), 57-61 